\title{
Lumen
}

Selected Proceedings from the Canadian Society for Eighteenth-Century Studies

\section{(De)Radicalism: Rootlessness and the Subversive Power of Money in Godwin's Caleb Williams and St. Leon}

\section{Aaron S. Kaiserman}

Volume 32, 2013

URI : https://id.erudit.org/iderudit/1015485ar

DOI : https://doi.org/10.7202/1015485ar

Aller au sommaire du numéro

Éditeur(s)

Canadian Society for Eighteenth-Century Studies / Société canadienne d'étude du dix-huitième siècle

ISSN

1209-3696 (imprimé)

1927-8284 (numérique)

Découvrir la revue

Citer cet article

Kaiserman, A. S. (2013). (De)Radicalism: Rootlessness and the Subversive Power of Money in Godwin's Caleb Williams and St. Leon. Lumen, 32, 73-84. https://doi.org/10.7202/1015485ar 


\title{
(De)Radicalism: Rootlessness and the Subversive Power of Money in Godwin's Caleb Williams and St. Leon
}

\author{
Aaron S. Kaiserman \\ University of Ottawa
}

It is unsurprising that William Godwin, a thinker whose major project was considered by critics to be an upheaval of all inherited tradition, would focus on questions of rootlessness in his first two novels. Both Caleb Williams and St. Leon present heroes who are plagued by the inability to maintain connections with other individuals as a result of past actions and suffer for having negative or unknown reputations. Although the heroes are uprooted from their past through calumny and poor judgment, they attempt to define themselves by present action and good intentions, rather than by the prejudices of the societies that have cast them out. Williams and St. Leon each develop a pattern of thought in which they see themselves both as outsider and member; they at once reject the opinion of society, instead favoring pure reason and an obstinate sense of righteousness, and maintain the importance of living in and supporting that society. Their constant changes of disguise, wandering, concealment, imprisonment, and miscalculated attempts at benevolence all reveal the impossibility of escaping the past. This characterizes a significant problem in Godwin's attitude toward reform: the necessity of uprooting the past in order to create a rational future contrasts with the impossibility, even undesirability, of being free from history. Although the prejudices of society are the bugbear of Godwinian thought, Godwin's novels nevertheless lament the individual's alienation from society as a result of rejecting its constraints. The tension between rational commitment to change 
and the individual's need for community undermines Godwin's confidence in reform. Godwin presents strategies for resolving this tension by exploring outsider communities, such as the romanticized banditti and Jews, which demonstrate alternate modes of social organization that exist in opposition to or disjunction from the larger social body. Godwin defines each of these groups through their relationships to money and exchange, thereby opposing them to the landed gentry's interest in hereditary property and demonstrating that the deracination of wealth that Godwin's revolutionary politics entail will lead to a more just society.

In order to describe "things as they are," Godwin states in the preface of Caleb Williams that he wishes to produce a "general review of the modes of domestic and unrecorded despotism by which man becomes the destroyer of man." Falkland, as the main antagonist, represents this mode of despotism as he, an apparently virtuous man, becomes corrupted by cultural norms: in this case, pride of station. Donald Roemer argues that Falkland's “ruling passion of public honour is a value esteemed in a monarchical society. While this value ideally generates positive qualities proven by Falkland as a paragon of benevolence, it is dangerously founded upon the egoistic desire for esteem. This man of feeling behaves virtuously out of love for his honourable reputation, but he also secretly murders Tyrell to preserve his selfesteem." ${ }^{2}$ The preservation of reputation is, of course, Caleb's project as well. The claim to reputation, or personal history, parallels claims on property throughout the novel: Tyrell's reputation remains fixed in the eyes of the public and he will brook no challenges, while Caleb's past, already unstable because he is an orphan and a servant, is further disrupted and distorted by Falkland's calumny and Caleb's own adoption of various disguises. Caleb's embrace of unstable identity, according to Jacques Khalip, is ultimately empowering: "Indeed, it is by turning the concept of anonymity into a full-scale political theory in Caleb Williams that Godwin makes his mark: narrative uncertainties and character unravelings intimate that subjectivity is politically viable

1. William Godwin, Caleb Williams, eds. Gary Handwerk and A.A. Markley (Peterborough: Broadview, 2000), 55.

2. Donald Roemer, "The Achievement of Godwin's Caleb Williams: The ProtoByronic Squire Falkland," Criticism 18.1 (1976): 46. 
because it is easily substituted, mobile and, betrayable." ${ }^{3}$ A flexible relationship to one's own character creates "anonymous mobility." 4. Similarly, connection to property limits freedom of mobility for both tenant and landholder, while commerce empowers individuals and thus promotes justice.

The ownership of land is central to the plot, and the characters' relationship to land defines the limits of their power. Falkland presents such an idea to Tyrell in order to remind him of his duty to the Hawkins:

There is a distinction of ranks. I believe that distinction is a good thing, and necessary to the peace of mankind. But, however necessary it may be, we must acknowledge that it puts some hardship on the lower orders of society. It makes one's heart ache to think, that one man is born to the inheritance of every superfluity, while the whole share of another, without any demerit of his, is drudgery and starving; and that all this is indispensible. ${ }^{5}$

This commonplace argument comes just after the reader has learned how the Hawkins have been oppressed by their landlord and have removed to Tyrell's land for protection. Now, having offended Tyrell, he turns against them. The Hawkins, uprooted and transplanted to Tyrell's property, lack any hereditary connection to this land, leaving them exposed to Tyrell's power. Falkland will later do the same to Caleb.

Caleb, an orphan and a servant, lives, like the Hawkins, by the mercy of his patron, Falkland. Godwin links the threat to Falkland's reputation with the power relations between gentry and commoners, since Falkland requires the love of the public to maintain control over them. In their discussion of Alexander the Great, Falkland and Caleb represent two differing political ideologies. Caleb's criticisms reveal an egalitarian spirit, an attitude that he assumes Falkland shares. Indeed, much of what Caleb and the reader know of Falkland tends toward this conclusion. But Falkland only acts in defense of the common man as a way of advancing his own reputation. Like Tyrell, his power is

3. Jacques Khalip, Anonymous Life: Romanticism and Dispossession (Stanford: Stanford University Press, 2009), 73.

4. Khalip, 74.

5. Godwin, Caleb Williams, 143. 
despotic; Falkland merely succeeds in being loved, as well as feared. He reveals the depth of his contempt for commoners in his admiration of Alexander who had to proclaim himself a god, as this was "the only way by which he could get a firm hold on the veneration of the stupid and bigoted Persians." Falkland also compares the death of a hundred thousand men to the death of as many sheep in relation to the greatness of Alexander's civilizing project. ${ }^{7}$ Caleb implicitly connects Alexander's propensity for slaughter to Falkland's crime of murder, and Falkland's ensuing "confusion" completes this link; as magnanimous as Falkland appears, Caleb understands that he is as brutal and vain as Alexander (and Tyrell), and that his actions all tend toward supporting his self image as a man above others. This is all in accordance with social systems in place in Britain-the notion of rank supports Falkland and his ability to enforce his superiority is connected to his ownership of land and title. Caleb becomes a villain in the eyes of the public for violating the relationship between master and servant, both when he allegedly steals from his master and when he threatens to reveal Falkland's secrets. The point is that Caleb suffers because the systems in place in Britain allow Falklands and Tyrells to exist and grants them immense power over other men. At the same time, it must be remembered that landholders rely on both the labour and good opinion of their tenants for success, and this symbiotic relationship is likewise harmful for the gentry, according to Godwin, as evidenced by both Tyrell's and Falkland's downfalls.

In order to demonstrate how Godwin attacks hierarchical institutions of this kind, I refer to Gilles Deleuze and Felix Guattari's A Thousand Plateaus to discuss how the concept of roots factor into hegemony. Deleuze and Guattari define rhizomes against roots and these terms represent two very different kinds of thought. Roots are sequential, hereditary, and linear: they create clear links between people and land and define relationships of power. Rhizomes, by contrast, spread out in all directions and are associated with nonhierarchical systems, or exist despite hierarchy and control. Rhizomes can upset the balance of power since "a rhizome ceaselessly establishes connections between semiotic chains, organizations of power, and 
circumstances relative to the arts, sciences, and social struggles." Rootedness implies a one-to-one, direct relationship between all parts, but rhizomes operate on multiple levels and can therefore disrupt existing power relations by finding parallel and alternative connections. Eighteenth-century British society, with its strict organization of rank and heritage, can be likened to a system of roots. Godwin explores less grounded social systems-rhizomatic ones-in order to criticize "things as they are."

Uprooted from ordinary society, Caleb explores alternatives to the community systems he knows, all with limited success. Yet Godwin includes these rhizomatic communities in order to demonstrate points of attack, not to liberate Caleb. When he falls into the group of bandits, Caleb praises their liberty and self-possession. Most importantly, he notes that unlike ordinary members of society, "they did not impose upon themselves the task ... of seeming tacitly to approve that from which they suffered most; or, which is worse, of persuading themselves that all the wrongs they suffered were right; but were at open war with their oppressors." Caleb approves of the banditti spirit, but cannot condone their way of living by thievery because "in their self-authorization of absolute will, these thieves operate very much like that other elite absolutist, Falkland." ${ }^{10}$ Nevertheless, the bandits form a stable, egalitarian community and their loyalty to each other is unquestioned. Though faulty, their system is superior to the one which, they argue, gives power to men "who are thieves according to law." are equal among themselves and are freer than other British subjects because they reject the strict hierarchies and stability of law that exist in Britain. They live for the present and do not judge each other by their pasts, as Godwin makes clear when the bandit leader Captain Raymond defends Caleb. For him, Caleb's past is irrelevant when his immediate condition is destitution. Justice demands that Caleb receive compassion and support. Raymond argues that his sense of justice is

8. Gilles Deleuze and Felix Guattari, A Thousand Plateaus: Capitalism and Schizophrenia (Minneapolis: University of Minnesota Press, 1987), 7.

9. Godwin, Caleb Williams, 309.

10. Erin Mackie, Rakes, Highwaymen, and Pirates: The Making of the Modern Gentleman in the Eighteenth Century (Baltimore: Johns Hopkins University Press, 2009), 189.

11. Godwin, Caleb Williams, 307. 
godlike because he forgives sin, and he laments that human laws are not so just. ${ }^{12}$ Nevertheless, Caleb finally convinces even this leader that thievery is wrong, and that his way of life is not, ultimately, just.

Godwin presents a second community of outcasts in Caleb Williams: Jews. It is worth noting that Caleb's inspiration for his Jewish disguise is a member of the thieves' gang. Jews and the banditti both operate in a rhizomatic system. They are at home everywhere and not tied to land, but rather to each other and to commerce, itself rhizomatic. Jews therefore offer for Godwinian thought an alternative to the rule of rooted landholders and those who enjoy hereditary privilege. Jewsassociated with mobility, secrets, and mercantilism-are perfect opposites to the clearly delineated hierarchy of ranks to which Godwin objects. Money in particular defines the outsider in this novel, and much more so in St. Leon, because it can be dispersed indiscriminately and undermines landed interests. Caleb's alleged crime is transporting wealth from where it belongs in his master's house, symbolizing what I see as the essential conflict between opposing views on access to property-hereditary property versus free exchange. The bandits, obviously, live on theft; the Irish beggar persona on charity; and the Jewish disguise is linked to the sale of merchandise, in this case books. Of course, to contemporary readers, thoughts of usury, theft, and miserly hoarding would also be associated with Jews, though Godwin avoids these characterizations. These outsider communities all represent freer and more just relationships to money, and by detailing the prejudices against such individuals, Godwin creates more opportunities to criticize the status quo, which requires stable and clearly defined relationships between individuals and money.

St. Leon makes the connection between transportable wealth and revolution explicit. In that novel, Godwin elaborates on the themes of wandering and rootlessness. While Caleb Williams wanders around Britain only, St. Leon travels across Europe and discovers that his anomalous nature raises suspicion universally, not just in his native France. St. Leon's mysterious and easily moveable wealth aligns him with the Jews and bandits of Caleb Williams, despite his aristocratic background. This reinforces Erin Mackie's claim regarding Caleb Williams that "Godwin brings together the eighteenth-century . . . crim-

12. Godwin, Caleb Williams, 320. 
inal and gentleman, weaving them together through a series of doubled reversals."13 St. Leon readily accepts the secret of the philosopher's stone because, as a recovering gambling addict, the promise of unlimited wealth is, for him, irresistible; immortality is secondary. When he returns to France after gambling his estate away, he finds that being wealthy does not ingratiate him with his former associates, who require specific knowledge of where his money came from. Unable to reveal this secret, St. Leon cannot assure his honour, and he becomes an outcast. He is isolated not because of his immortality, but because no one will accept that his wealth is fairly won, and so the crucial distinction between the promise of unlimited wealth and the stable social status associated with real property drives the second half of the novel. Despite his best intentions, St. Leon fails because his rhizomatic wealth undermines human institutions which require detailed accounts of a man's history in order to establish his honour and virtue.

The most dramatic instance of this failure occurs when he adopts charitable projects in Hungary. Significantly, St. Leon initially succeeds. By acting discretely and moderately, he builds infrastructure in the war-torn region. But St. Leon soon finds that the local government does not appreciate his efforts. The bashaw accuses him of being "one of those busy-bodies, who never see an evil without imagining that they are the person to correct it, intruding into every thing, and subverting every thing." ${ }^{14}$ St. Leon's interference is labeled both treason and blasphemy because, as in Christian Europe, rank in Turkishoccupied Hungary is structured through direct hierarchical relationships:

The sovereign of Constantinople will have no benefactor in the countries he presides over, but himself. Like the invisible ruler of the universe, he acts by second causes; he allows his ministers to be instruments of his beneficence; but all must be ascribed to him, must flow from his will, and be placed under his control. ${ }^{15}$

St. Leon interferes with this order when he resolves to "pour the entire stream of my riches, like a mighty river, to fertilize these wasted plains,

13. Mackie, 182.

14. William Godwin, St. Leon, ed. William Brewer (Peterborough: Broadview, 2006), 376 .

15. Godwin, St. Leon, 376. 
and revive their fainting inhabitants." ${ }^{6}$ Goods which ought to flow from the top down are instead distributed laterally by St. Leon. He multiplies the sources of wealth and therefore destabilizes the power of a monarch by showing the people alternate means of support. The bashaw reacts to this by extorting bribes from St. Leon in exchange for protection and sanction within the hierarchy, which in turn diminishes the threat of St. Leon's interference. The central irony of St. Leon is that infinite wealth is disempowering, not because the Philosopher's Stone corrupts the man, but because society itself is corrupt. Without the stability of hereditary roots and "real" property, money makes St. Leon vulnerable to extortion or imprisonment by those who do have reputation and authority.

Both Caleb Williams and St. Leon disguise themselves to avoid these abuses, and both are unsuccessful. Eric Daffron notes that Caleb's disguises fail "because the personae he chooses to imitate actually expose rather than conceal his presence," since "as a lower class farmer's son ... he shares a marginal, nearly outlawed status with the Irish beggar, the wandering Jew and the disabled."17 Further, Mackie shows how Caleb becomes fascinated with the exaggerated accounts he hears of his own exploits and develops a psychological attachment to his fictive self. ${ }^{18}$ It is much the same for St. Leon. As Chatillon, St. Leon's wealth remains mysterious, since this persona has an even shadier past. As D'Aubigny, he allows his indiscriminate displays of wealth to interfere in his son's life, and almost undoes the marriage between Charles and Pandora. Only as the Armenian merchant, a character quite removed from his original identity, does St. Leon successfully disguise himself, allowing him to see his daughters and smooth away the lasting impact of his own misconduct on their honour. Michael Scrivener discusses this disguise as the last in a series of allusions that links St. Leon with Jews, through the confluence of associations with persecution, "merchants, and . . . scholars."19 The fluidity of both money and identity traditionally associated with

16. Godwin, St. Leon, 360 .

17. Eric Daffron, “Magnetical Sympathy': Strategies of Power and Resistance in Godwin's Caleb Williams,” Criticism 37.2 (1995): 228.

18. Mackie, $189-90$.

19. Michael Scrivener, Jewish Representation in British Literature 1780-1840 (New York: Palgrave Macmillan, 2011), 108. 
Jews grants St. Leon power to succeed in this instance. This is also the only disguise that complements St. Leon's status as a wandering Jew figure, and it thus grants a ready-made excuse for his wealth and unknown past.

The various roles and disguises in both novels-such as the Jews, the Irish beggar, the banditti and the rejuvenated St. Leon-reject the primacy of social rank and transgress borders, transporting money and undermining its cultural meaning by challenging the superiority of landed wealth. The timing of St. Leon's transformation, when he drinks the elixir of life and returns to youth, links all of these themesrootlessness, money and revolution-together. After escaping the inquisition, St. Leon stumbles upon a Jew's house and hides there. St. Leon threatens the Jew, symbolically reproducing the tyranny St. Leon has himself suffered at the hands of the inquisition. He borrows a suit of clothes, concocts the elixir and drinks it while the Jew and his daughter are asleep. Now, wearing the Jew's clothes, St. Leon looks in the mirror and sees a twenty-year-old version of himself. He achieves the ultimate disguise by becoming young again, and he does this in the home of a Jew who has only nominally converted to Christianity in order to save his life. The crypto-Judaism of his host mirrors St. Leon's disguise and both characters are, on some level, at war with their surroundings. Neither has any strong tie to the societies they live in and both are intimately associated with money. At the same time, both are continually exposed to threats from others. There is one difference, however: St. Leon has by now severed all ties with his family, whereas the Jew clings to family as his one security in life, avowing that "we poor Jews, hunted on the face of the earth, the abhorrence and execration of mankind, have nothing but family connections to support us under our multiplied disgraces; and family affections are entwined with our existence, the fondest and best-loved part of ourselves. ${ }^{20}$ Even the most abused people, according to Godwin, still value family connections - ties that St. Leon trades for the Philosopher's Stone and the power it offers.

This need for family or friendship presents the biggest challenge for Godwin in making his case against the social order. Godwin condemns hereditary distinctions and arbitrary power throughout both 
novels, as their uprooted heroes provide examples of the abuses of power and the potential to effect change by subverting the existing power relations. Yet St. Leon and Caleb's alienation are in no way desirable. In St. Leon's case this is especially so because he loses all ties to his family. Louise Joy argues that though Godwin professes to have written St. Leon as a way of amending his theories and to embrace family affections as consonant with political justice, the gesture is at times hollow, since he generally glosses over the domestic scenes in order to get to the supernatural tale, and St. Leon laments the loss of domestic life, rather than celebrating its presence. Joy demonstrates that St. Leon's reflection on his losses "takes him away from the more practical ends he should be serving."2l Godwin appears to value family greatly in St. Leon, but severing that tie allows St. Leon a much greater scope for justice. Family, and the rootedness it represents, is nevertheless held up as the forum for self-fulfillment; without it, St. Leon can only be an aimless wanderer, disrupting society, but never actually changing it.

The resolution of Caleb Williams is equally divided. Falkland attempts to restrict Caleb's movement, to ground him in Britain, but of course, Falkland's efforts to reduce Caleb's power also diminish his own. Falkland tries to keep Caleb rooted within the hierarchy of a master-slave relationship. But Caleb attempts to move beyond this and spread out rhizomatically: incorporating elements of the individuals he encounters and mimics, developing a multiplicity of roles, and thereby throwing off the logic of Falkland's system of unified hierarchy. In his last, triumphant, moment, Caleb mimics Falkland himself by forgiving him in a show of sympathy that recalls the earlier encounter in which Falkland claims to forgive Caleb. In the contest of martyrdom, Caleb prevails because he suffers harsher punishment for lesser crimes. But despite this triumph against tyranny that culminates in Falkland's confession, Caleb excoriates himself as the "basest and most odious of mankind" for exposing Falkland's tyrannical behaviour. ${ }^{22}$ Donald Wehrs explains this by arguing that "Caleb Williams begins with the intent of exposing the frauds of eighteenth-century fiction but

21. Louise Joy, "St. Leon and the Culture of the Heart," History of European Ideas, 33.1 (2007): 48 .

22. Godwin, Caleb Williams, 431. 
ends by questioning the moral consequences of unmasking them for the sake of abstract "truth." 23 The original, unpublished ending of the novel obviates this dilemma by reasserting the primacy of reputation over truth when Falkland asserts before the court that "the character of neither of the parties ... was wholly unknown" and that Caleb is "a thief; breaker of prisons; and last a consummate adept in every species of disguise ... Which of the two would they believe?"24 Caleb embraces his reputation after being imprisoned, accepting even the accusations of supernatural abilities ascribed to him: "Why should I, who have broken fetters, and made my way through walls of stone, doubt of my deliverance from this new confinement?"25 This version, more so than the published ending, demonstrates the impossibility of justice in Godwin's England. Caleb's identification with his criminal reputation and his subsequent madness in turn results in his self-conception as "A GRAVESTONE ... WHAT WAS ONCE A MAN," 26 and this parallels Caleb's claim in the published ending that "I have now no character that I wish to vindicate." 27 This emptying out of identity and rejection of all value in Caleb's past behaviour reinforces Khalip's assertion that "Godwin . . . in the delineation of a character without properties and a novel without a reliable narrator, effectively suspends judgement over the very events and persons he seeks to dramatize."28 Because there is no objective truth, and therefore no concrete sense of identity or history, the injustice Caleb claims to expose cannot be believed, and he is left lamenting the steps he took that led to his persecution and imprisonment. In the original ending, at least, Falkland confirms Caleb's accusations in public and justifies Caleb's alienation from society, since it ultimately produces justice.

Still, because Caleb regrets forcing Falkland to confess, identifies with his persecutor, and rejects all his own rebellious actions, both endings of the novel tend to undermine Godwin's revolutionary argument. Yet the reader, presumably, is not meant to identify with either

23. Donald Wehrs, "Rhetoric, History, Rebellion: Caleb Williams and the Subversion of Eighteenth-Century Fiction," Studies in English Literature, 1500-1900, 28.3 (1988): 508.

24. Godwin, Caleb Williams, 437.

25. Godwin, Caleb Williams, 440.

26. Godwin, Caleb Williams, 443.

27. Godwin, Caleb Williams, 434.

28. Khalip, 95 . 
Caleb or Falkland. She or he, having been alerted to the injustice of "things as they are," is expected to read critically and participate in the revolutionary spirit of the novel. In this reading, the novel testifies to the notion that an individual can be defeated, but not an idea: "a rhizome may be broken, shattered at a given spot, but it will start up again on one of its old lines, or on new lines." ${ }^{29}$ Taking Deleuze and Guattari's concepts in mind, the published ending is less problematic and can be instead read as one more iteration of the effects tyranny and one more call for resistance.

On the level of plot, though, St. Leon and Caleb Williams do not favour the man who leaves society, nor are the heroes' commitments to justice fulfilled. And so Godwin presents the reader with a difficult challenge: we must see the causes and effects of tyranny, but must not distance ourselves wholly from the social conditions that can produce injustice. St. Leon vacillates in his commitment to family, and Caleb's loves of truth and of his master are incompatible-tensions that ultimately render both protagonists powerless. Over the course of their wanderings, however, both demonstrate certain loci of subversion: most importantly, the power of commerce to permeate various institutions. It remains unclear whether Godwin faults St. Leon and Caleb Williams more for their violation of social order, or for their lack of nerve in doing so.

29. Deleuze and Guattari, A Thousand Plateaus, 9. 